\title{
Effect of Dietary Dried Oregano Leaves Supplementation on Broiler Performance
}

\author{
Fazhana Ismail ${ }^{1}$, Abdul S. Chaudhry ${ }^{2}$ and Sandra Edwards ${ }^{2}$ \\ ${ }^{1}$ Faculty of Technical and Vocational Education, Sultan Idris Education University, 35900 Tanjung Malim, \\ Perak, Malaysia \\ ${ }^{2}$ School of Agriculture, Food and Rural Development, Newcastle University, NE17RU, United Kingdom
}

\begin{abstract}
Herb is one of a potential alternative to antibiotic growth promoters (AGPs) in poultry feed. In this study, four different levels of dried oregano leaves $(0,1,3$ and $9 \mathrm{~g} / \mathrm{kg}$ diet) were tested in 120 day old male chicks allocated into 4 groups with 6 replicates and 5 birds each for 42 days. Weekly growth performance and carcass yield were recorded. It was found that feeding dried oregano leaves will reduce the broiler daily feed intake and at the same time reduced their body weight gain. Feed conversion ratio was significantly $(P<0.05)$ improved in broiler fed with $9 \mathrm{~g} / \mathrm{kg}$ diet. Feeding dried oregano leaves did not affect the carcass yield percentage. In conclusion, dried oregano leaves could be fed to the broiler to improve their feed efficiency and did not harmful on their carcass yield.
\end{abstract}

Keywords: herb, broiler, dried oregano leaves, phytogenic

\section{Introduction}

Recent concern on public health and food safety embarking the scientist to find many alternative of antibiotic growth promoter (AGPs) in animal feed. The feed additives should be safe, cost effective, healthy and efficient so that the quality and quantity of animal product will be improved or other way maintain as if using the AGPs. One of the popular feed additive being researched and interest to many researcher is from herb or plant based which is also consumed in human food. Herb is very well known to increase metabolism rate and lead to improvement in broiler performance [4[. The active ingredient in herb is the main substance that play the major role to its functions. Oregano plant has been identified contained thymol and calcivrol which is the active ingredient in this herb and well known as antifungal [2] and antioxidant [1]

In most of the report in other studies, oregano essential oil has been applied in broiler with inconsistent results. Oregano essential oil has a very intense smell. Adding oregano essential oil in broiler feed has been reported to cause negative alteration on feeding and drinking behaviour in female broiler [5]. Dried oregano leaves are simpler and easier to be added in broiler feed. A study on dried oregano leaves in female turkey by Florou-Paneri et al [3] found that neither feed intake nor daily weight gain was improved but effective to delay lipid oxidation of breast and thigh meat of female turkey. To our knowledge, there is a lack of report on effect of dried oregano leaves in male broiler. Therefore, in current study, different level of dried oregano leaves was applied and the effects on broiler growth performance and carcass quality were observed.

\section{Materials \& Methodologies}

A total of 120 day-old Ross 308 male chicks were divided into 4 groups with 6 replicates contain 5 birds each. They were placed in floor pens and provided with new saw-dust and heater for the first 7 days. There were fed on assigned feed treatments (Table 1); CTL (basal diet); DOL1 (basal diet $+1 \mathrm{~g}$ DOL/kg diet); DOL3 (basal 
diet $+3 \mathrm{~g} \mathrm{DOL} / \mathrm{kg}$ diet) and DOL9 (basal diet $+9 \mathrm{~g}$ DOL $/ \mathrm{kg}$ diet). They were fed and drink ad libitum. Weekly body weight and feed intake were recorded. 4 birds from each treatment were killed on D7, D21 and D42 to determine the carcass quality. Carcass weight which included the heart, gizzard, liver and intestine (commercial carcass) as percentage value were recorded. Heart, breast, thigh and legs, gizzard and liver weight as percentage of eviscerated weight were also recorded.

TABLE 1: Composition Of Basal Diet

\begin{tabular}{lllc}
\hline Components & g/kg & Chemical composition & 3025 \\
\hline Wheat & 623 & ME, kcal/kg & 197.1 \\
Wheatfeed & 90 & $\mathrm{CP}, \mathrm{g} / \mathrm{kg}$ & 9.0 \\
Soybean meal, 48\% & 223 & Calcium, g/kg & 2.5 \\
Vegetable oil & 27.5 & Available P, g/kg & 9.9 \\
Vitamin-mineral premix & 4 & Digestible Lys, g/kg & 4.7 \\
Sodium bicarbonate & 2.2 & Digestible Met, g/kg & 7.6 \\
Salt & 3.8 & Digestible Met + Cys, g/kg & 7.4 \\
Monocalcium phosphate & 1 & Digestible Thr, g/kg & 2.1 \\
Limestone & 16.9 & Digestible Trp, g/kg & \\
Lysine & 2.5 & & \\
DL-Methionine & 2.3 & & \\
L-Threonine & 1.9 & & \\
\hline
\end{tabular}

The premix provided the following (per $\mathrm{kg}$ ): Vitamin A 8,000 IU, vitamin $\mathrm{D}_{3} 1,600 \mathrm{IU}$, vitamin $\mathrm{E}$ $28 \mathrm{mg}$, vitamin $\mathrm{K}_{3} 1.68 \mathrm{mg}$, vitamin $\mathrm{B}_{1} 1.52 \mathrm{mg}$, vitamin $\mathrm{B}_{2} 5.2 \mathrm{mg}$, vitamin $\mathrm{B}_{6} 2 \mathrm{mg}$, vitamin $\mathrm{B}_{12} 0.012 \mathrm{mg}$, calcium pantothenate $8 \mathrm{mg}$, nicotinamide $20 \mathrm{mg}$, biotin $0.04 \mathrm{mg}$, folic acid $0.48 \mathrm{mg}, \mathrm{Cu} 8 \mathrm{mg}, \mathrm{Zn} 80 \mathrm{mg}, \mathrm{Fe}$ $72 \mathrm{mg}$, Mn $72 \mathrm{mg}$, Se $0.32 \mathrm{mg}$, I $0.6 \mathrm{mg}$.

\section{Statistical Analysis}

Average body weight gain, feed intake and feed conversion ratio (FCR) were recorded and analysed using Minitab Version 17.0 and significance was determined by simple ANOVA. Any significant $(\mathrm{P}<0.05)$ value was differentiated by Tukey test. The value is reported as growing phase basis (starter, grower and finisher). Carcass quality was analysed using same software programme and reported as relative percentage of eviscerated weight.

\section{Results and discussions}

\subsection{Growth Performances}

Table II summarizes the effect of the treatment on average daily feed intake during starter, grower and finisher phase and in total 42 days experiment period.

During starter phase (D0-14), group DOL9 was significantly $(\mathrm{P}<0.05)$ ate lesser $(29.03 \pm 2.18 \mathrm{~g} / \mathrm{d} / \mathrm{bird})$ compared to other groups. During grower phase $(\mathrm{D} 15-28)$, it was significantly $(\mathrm{P}<0.05)$ reduction in feed intake in all DOL-treated groups. However, there was no any difference $(\mathrm{P}>0.05)$ between CTL (109.88 \pm $10.29 \mathrm{~g} / \mathrm{d} / \mathrm{bird})$ and DOL1 $(95.41 \pm 10.82 \mathrm{~g} / \mathrm{b} /$ day $)$. The reduction in feed intake was consistently observed in all DOL- treated groups during finisher and significantly lower $(\mathrm{P}<0.05)$ compared to CTL $(206.93 \pm 11.44 \mathrm{~g} / \mathrm{d} / \mathrm{bird})$. In total for 42 days experimental period, birds in CTL ate higher $(118.11 \pm 5.13$ $\mathrm{g} / \mathrm{d} / \mathrm{bird}, \mathrm{P}<0.05)$ compared to all DOL-treated groups. Higher level of DOL in the diet resulted lower feed intake even though there was not statistically different $(\mathrm{P}>0.05)$ between DOL1(98.64 $\pm 4.62 \mathrm{~g} / \mathrm{d} / \mathrm{bird})$ to DOL3 $(96.67 \pm 5.35 \mathrm{~g} / \mathrm{d} / \mathrm{bird})$ and between DOL3 to DOL9 $(83.45 \pm 4.07 \mathrm{~g} / \mathrm{d} / \mathrm{bird})$. 
Table II. Average Daily Feed Intake (ADFI) on Broiler Fed Different Level of DOL (G/B)

\begin{tabular}{ccccc}
\hline Diet $^{1}$ & FI & FI & FI & FI \\
& D0-14 & D15-28 & D29-42 & D0-42 \\
\hline CTL & $37.50^{\mathrm{a}}$ & $109.88^{\mathrm{a}}$ & $206.93^{\mathrm{a}}$ & $118.11^{\mathrm{a}}$ \\
DOL1 & $34.67^{\mathrm{a}}$ & $95.41^{\mathrm{ab}}$ & $165.85^{\mathrm{b}}$ & $98.64^{\mathrm{b}}$ \\
DOL3 & $35.99^{\mathrm{a}}$ & $94.16^{\mathrm{b}}$ & $159.8^{\mathrm{b}}$ & $96.67^{\mathrm{bc}}$ \\
DOL9 & $29.03^{\mathrm{b}}$ & $85.65^{\mathrm{b}}$ & $135.68^{\mathrm{b}}$ & $83.45^{\mathrm{c}}$ \\
SEM & 1.86 & 9.63 & 23.74 & 8.66
\end{tabular}

${ }^{1}$ CTL: basal diet without any feed additive; DOL1: CTL+1g DOL/kg diet; DOL3: CTL + 3g DOL/kg diet; DOL9: CTL+ 9g $\mathrm{DOL} / \mathrm{kg}$ diet.

Means in the row that do not share a letter are significantly different $(\mathrm{P}<0.05)$

Table III. summarizes the effect of different level of DOL in broiler body weight gain (BWG) at different growing phase.

Day-old chicks (DOC) with uniform ( $\mathrm{P}>0.05)$ body weight were used in this trial range from $45.8 \pm$ 1.31 to $46.07 \pm 0.69 \mathrm{~g} / \mathrm{bird}$. During starter phase, birds in DOL9 gained lower $(\mathrm{P}<0.05)$ compared to other groups. However, birds in all groups were not different $(\mathrm{P}>0.05)$ in body weight gain during grower phase. Surprisingly, all DOL-treated groups gained lower $(\mathrm{P}<0.05)$ compared to CTL during finisher phase. No any difference $(\mathrm{P}>0.05)$ was observed between DOL-treated groups. As general, during 42 days experimental period, all DOL-treated groups gained lower $(\mathrm{P}<0.05)$ than $\mathrm{CTL}$ but no difference $(\mathrm{P}>0.05)$ between DOL-treated groups.

Table III. Average body weight gain (BWG) in broiler fed on different level of DOL (g/bird/day)

\begin{tabular}{cccccc}
\hline Diet $^{1}$ & Initial BW & BWG & BWG & BWG & BWG \\
& D0 & D0-14 & D15-28 & D29-42 & D0-42 \\
\hline CTL & $45.93^{\mathrm{a}}$ & $25.96^{\mathrm{a}}$ & $64.43^{\mathrm{a}}$ & $119.69^{\mathrm{a}}$ & $2941.1^{\mathrm{a}}$ \\
DOL1 & $46.00^{\mathrm{a}}$ & $24.79^{\mathrm{a}}$ & $61.57^{\mathrm{a}}$ & $95.25^{\mathrm{b}}$ & $2542.5^{\mathrm{b}}$ \\
DOL3 & $46.07^{\mathrm{a}}$ & $25.63^{\mathrm{a}}$ & $59.42^{\mathrm{a}}$ & $89.26^{\mathrm{b}}$ & $2440.4^{\mathrm{b}}$ \\
DOL9 & $45.80^{\mathrm{a}}$ & $21.34^{\mathrm{b}}$ & $64.54^{\mathrm{a}}$ & $85.97^{\mathrm{b}}$ & $2405.9^{\mathrm{b}}$ \\
SEM & 1.41 & 1.90 & 4.02 & 9.08 & 136.43 \\
\hline
\end{tabular}

${ }^{1}$ CTL: basal diet without any feed additive; DOL1: CTL+1g DOL/kg diet; DOL3: CTL + 3g DOL/kg diet; DOL9: CTL+ 9g $\mathrm{DOL} / \mathrm{kg}$ diet.

Means in the row that do not share a letter are significantly different $(\mathrm{P}<0.05)$

Average Daily Gain (ADG) in 42 days experimental period is tabulated in Table IV. Birds in CTL gained higher $(\mathrm{P}<0.05)$ compared to all other DOL-treated groups. There was reduction in ADG as DOL level getting higher even though there was no significant $(\mathrm{P}>0.05)$ difference between DOL-treated groups.

Table IV. Average Daily Gain (ADG) D0-42 on broiler fed different level of DOL (g/b/d)

\begin{tabular}{cc}
\hline Diet $^{1}$ & ADG \\
\hline CTL & $70.02^{\mathrm{a}} \pm 2.41$ \\
DOL1 & $60.54^{\mathrm{b}} \pm 2.43$ \\
DOL3 & $58.10^{\mathrm{b}} \pm 4.96$ \\
DOL9 & $57.28^{\mathrm{b}} \pm 2.44$ \\
SEM & 3.25 \\
\hline
\end{tabular}

${ }^{1}$ CTL: basal diet without any feed additive; DOL1: CTL+1g DOL/kg diet; DOL3: CTL + 3g DOL/kg diet; DOL9: CTL+ 9g $\mathrm{DOL} / \mathrm{kg}$ diet.

Means in the row that do not share a letter are significantly different $(\mathrm{P}<0.05)$ 
Table V. shows feed conversion ratio (FCR) at different growing phase and in total for 42 days experimental period. During starter phase, FCR in CTL was highest $(1.45 \pm 0.07 \mathrm{~g}$ feed/ $\mathrm{g}$ BWG) but not different $(\mathrm{P}>0.05)$ to all other DOL-treated groups. During grower phase, it showed a reduction pattern in FCR in DOL-treated groups. FCR in CTL $(1.70 \pm 0.13 \mathrm{~g}$ feed $/ \mathrm{g}$ BWG $)$ was significant $(\mathrm{P}<0.05)$ higher compared to DOL9 $(1.33 \pm 0.17 \mathrm{~g}$ feed/ $\mathrm{g}$ BWG). However, FCR in CTL did not different $(\mathrm{P}>0.05)$ compared to DOL1 $(1.55 \pm 0.18 \mathrm{~g}$ feed/g BWG) and DOL3 $(1.60 \pm 0.21 \mathrm{~g}$ feed/ g BWG). Surprisingly, FCR was not statistically different $(\mathrm{P}>0.05)$ between groups during finisher phase. In general, during 42 days experimental period, FCR in CTL $(1.69 \pm 0.06 \mathrm{~g}$ feed/g BWG) was significantly $(\mathrm{P}<0.05)$ higher compared to highest DOL-level treated group, DOL9 $(1.46 \pm 0.08 \mathrm{~g}$ feed/g BWG). However, FCR in CTL was not significantly $(\mathrm{P}>0.05)$ different compared to DOL1 $(1.63 \pm 0.13 \mathrm{~g}$ feed/ $\mathrm{g}$ BWG) and DOL3 (1.66 \pm $0.19 \mathrm{~g}$ feed / $\mathrm{g}$ BWG).

Table V. Weekly feed conversion ratio (FCR) on broiler fed different level of DOL

\begin{tabular}{ccccc}
\hline Diet $^{1}$ & FCR & FCR & FCR & FCR \\
& D0-14 & D15-28 & D29-42 & D0-42 \\
\hline CTL & $1.45^{\mathrm{a}}$ & $1.70^{\mathrm{a}}$ & $1.73^{\mathrm{a}}$ & $1.69^{\mathrm{a}}$ \\
DOL1 & $1.41^{\mathrm{a}}$ & $1.55^{\mathrm{ab}}$ & $1.75^{\mathrm{a}}$ & $1.63^{\mathrm{ab}}$ \\
DOL3 & $1.42^{\mathrm{a}}$ & $1.60^{\mathrm{ab}}$ & $1.76^{\mathrm{a}}$ & $1.66^{\mathrm{ab}}$ \\
DOL9 & $1.36^{\mathrm{a}}$ & $1.33^{\mathrm{b}}$ & $1.59^{\mathrm{a}}$ & $1.46^{\mathrm{b}}$ \\
SEM & 0.14 & 0.18 & 0.19 & 0.13
\end{tabular}

${ }^{1}$ CTL: basal diet without any feed additive; DOL1: CTL+1g DOL/kg diet; DOL3: CTL + 3g DOL/kg diet; DOL9: CTL+ 9g $\mathrm{DOL} / \mathrm{kg}$ diet.

Means in the row that do not share a letter are significantly different $(\mathrm{P}<0.05)$

\subsection{Carcass Evaluation}

Effect of different level of DOL on broiler carcass at different age is tabulated in Table VI, VII and VII. During D7, eviscerated weight as percentage to the carcass weight was not statistically different $(\mathrm{P}>0.05)$ between groups. Breast, thigh and legs, liver and spleen weight percentage were also not significantly different $(\mathrm{P}>0.05)$ between groups. Gizzard and heart percentage in DOL9 was significantly $(\mathrm{P}<0.05)$ higher compared to CTL. However, no difference $(\mathrm{P}>0.05)$ among DOL-treated groups was observed.

Table VI . Effects of DOL on carcass yield of broiler chickens on D7

\begin{tabular}{cccccccc}
\hline Diet $^{1}$ & $\begin{array}{c}\text { Eviscerated } \\
\text { weight } \\
(\%)\end{array}$ & $\begin{array}{c}\text { Breast } \\
(\%)\end{array}$ & $\begin{array}{c}\text { Thigh }+ \\
\text { legs } \\
(\%)\end{array}$ & $\begin{array}{c}\text { Gizzard } \\
(\%)\end{array}$ & $\begin{array}{c}\text { Liver } \\
(\%)\end{array}$ & $\begin{array}{c}\text { Spleen } \\
(\%)\end{array}$ & $\begin{array}{c}\text { Heart } \\
(\%)\end{array}$ \\
\hline CTL & $59.78^{\mathrm{a}}$ & $34.47^{\mathrm{a}}$ & $42.99^{\mathrm{a}}$ & $1.05^{\mathrm{b}}$ & $0.59^{\mathrm{a}}$ & $0.09^{\mathrm{a}}$ & $0.17^{\mathrm{b}}$ \\
DOL1 & $57.76^{\mathrm{a}}$ & $35.63^{\mathrm{a}}$ & $39.31^{\mathrm{a}}$ & $1.26^{\mathrm{ab}}$ & $0.66^{\mathrm{a}}$ & $0.17^{\mathrm{a}}$ & $0.22^{\mathrm{ab}}$ \\
DOL3 & $58.16^{\mathrm{a}}$ & $34.09^{\mathrm{a}}$ & $38.06^{\mathrm{a}}$ & $1.32^{\mathrm{ab}}$ & $0.79^{\mathrm{a}}$ & $0.15^{\mathrm{a}}$ & $0.25^{\mathrm{ab}}$ \\
DOL9 & $59.26^{\mathrm{a}}$ & $43.08^{\mathrm{a}}$ & $47.63^{\mathrm{a}}$ & $1.79^{\mathrm{a}}$ & $0.84^{\mathrm{a}}$ & $0.16^{\mathrm{a}}$ & $0.31^{\mathrm{a}}$ \\
SEM & 5.45 & 7.19 & 6.11 & 0.26 & 0.19 & 0.05 & 0.06 \\
\hline
\end{tabular}

${ }^{1}$ CTL: basal diet without any feed additive; DOL1: CTL+1g DOL/kg diet; DOL3: CTL + 3g DOL/kg diet; DOL9: CTL+ 9g $\mathrm{DOL} / \mathrm{kg}$ diet.

Means in the row that do not share a letter are significantly different $(\mathrm{P}<0.05)$

During D21, eviscerated weight percentage was still not significant different $(\mathrm{P}>0.05)$ among groups. Breast, thigh and legs, gizzard and liver weight percentage were also not statistically different $(\mathrm{P}>0.05)$ among groups. However, spleen and heart weight percentage in CTL was significantly lower $(\mathrm{P}<0.05)$ compared to DOL1 and DOL9. No any difference was observed in spleen and heart weight percentage in all DOL-treated groups. 
Table VII. Effects of DOL on Carcass Yield of Broiler Chickens on D21

\begin{tabular}{cccccccc}
\hline Diet $^{1}$ & $\begin{array}{c}\text { Eviscerated } \\
\text { weight } \\
(\boldsymbol{\%})\end{array}$ & $\begin{array}{c}\text { Breast } \\
(\boldsymbol{\%})\end{array}$ & $\begin{array}{c}\text { Thigh } \\
\mathbf{l e g s} \\
(\boldsymbol{\%})\end{array}$ & $\begin{array}{c}\text { Gizzard } \\
(\boldsymbol{\%})\end{array}$ & $\begin{array}{c}\text { Liver } \\
(\boldsymbol{\%})\end{array}$ & $\begin{array}{c}\text { Spleen } \\
(\boldsymbol{\%})\end{array}$ & $\begin{array}{c}\text { Heart } \\
(\boldsymbol{\%})\end{array}$ \\
\hline CTL & $62.91^{\mathrm{a}}$ & $19.11^{\mathrm{a}}$ & $17.74^{\mathrm{a}}$ & $3.27^{\mathrm{a}}$ & $2.70^{\mathrm{a}}$ & $0.18^{\mathrm{b}}$ & $0.53^{\mathrm{b}}$ \\
DOL1 & $63.81^{\mathrm{a}}$ & $18.69^{\mathrm{a}}$ & $16.53^{\mathrm{a}}$ & $3.55^{\mathrm{a}}$ & $3.51^{\mathrm{a}}$ & $0.28^{\mathrm{a}}$ & $0.73^{\mathrm{a}}$ \\
DOL3 & $64.17^{\mathrm{a}}$ & $16.85^{\mathrm{a}}$ & $16.61^{\mathrm{a}}$ & $2.71^{\mathrm{a}}$ & $3.43^{\mathrm{a}}$ & $0.23^{\mathrm{ab}}$ & $0.68^{\mathrm{ab}}$ \\
DOL9 & $63.44^{\mathrm{a}}$ & $16.42^{\mathrm{a}}$ & $20.29^{\mathrm{a}}$ & $3.48^{\mathrm{a}}$ & $3.62^{\mathrm{a}}$ & $0.29^{\mathrm{a}}$ & $0.79^{\mathrm{a}}$ \\
SEM & 4.64 & 4.77 & 2.78 & 0.86 & 0.46 & 0.05 & 0.08 \\
\hline
\end{tabular}

${ }^{1}$ CTL: basal diet without any feed additive; DOL1: CTL+1g DOL/kg diet; DOL3: CTL + 3g DOL/kg diet; DOL9: CTL+ 9g $\mathrm{DOL} / \mathrm{kg}$ diet.

Means in the row that do not share a letter are significantly different $(\mathrm{P}<0.05)$

During $\mathrm{D} 42$, no any difference $(\mathrm{P}>0.05)$ was observed in all groups in term of eviscerated carcass, breast, thigh and legs, gizzard, liver and spleen weight percentage. However, heart weight percentage was significantly higher in DOL9 compared to CTL and DOL1.

Table VIII. Effects of DOL on Carcass Yield of Broiler Chickens on D42

\begin{tabular}{cccccccc}
\hline Diet $^{1}$ & $\begin{array}{c}\text { Eviscerated } \\
\text { weight } \\
(\%)\end{array}$ & $\begin{array}{c}\text { Breast } \\
(\%)\end{array}$ & $\begin{array}{c}\text { Thigh }+ \\
\text { legs } \\
(\%)\end{array}$ & $\begin{array}{c}\text { Gizzard } \\
(\%)\end{array}$ & $\begin{array}{c}\text { Liver } \\
(\%)\end{array}$ & $\begin{array}{c}\text { Spleen } \\
(\%)\end{array}$ & $\begin{array}{c}\text { Heart } \\
(\%)\end{array}$ \\
\hline CTL & $53.66^{\mathrm{a}}$ & $25.82^{\mathrm{a}}$ & $16.71^{\mathrm{a}}$ & $1.88^{\mathrm{a}}$ & $2.92^{\mathrm{a}}$ & $0.07^{\mathrm{a}}$ & $0.73^{\mathrm{b}}$ \\
DOL1 & $58.04^{\mathrm{a}}$ & $26.44^{\mathrm{a}}$ & $16.85^{\mathrm{a}}$ & $1.94^{\mathrm{a}}$ & $3.21^{\mathrm{a}}$ & $0.09^{\mathrm{a}}$ & $0.76^{\mathrm{b}}$ \\
DOL3 & $52.14^{\mathrm{a}}$ & $32.9^{\mathrm{a}}$ & $16.46^{\mathrm{a}}$ & $2.50^{\mathrm{a}}$ & $4.04^{\mathrm{a}}$ & $0.12^{\mathrm{a}}$ & $0.87^{\mathrm{ab}}$ \\
DOL9 & $54.13^{\mathrm{a}}$ & $29.92^{\mathrm{a}}$ & $18.69^{\mathrm{a}}$ & $2.32^{\mathrm{a}}$ & $4.38^{\mathrm{a}}$ & $0.12^{\mathrm{a}}$ & $1.06^{\mathrm{a}}$ \\
SEM & 7.14 & 4.66 & 3.06 & 0.64 & 0.88 & 0.03 & 0.13 \\
\hline
\end{tabular}

${ }^{1}$ CTL: basal diet without any feed additive; DOL1: CTL+1g DOL/kg diet; DOL3: CTL + 3g DOL/kg diet; DOL9: CTL+ 9g $\mathrm{DOL} / \mathrm{kg}$ diet.

Means in the row that do not share a letter are significantly different $(\mathrm{P}<0.05)$

\section{Discussion}

Providing dried oregano leaves at any level to broiler reduced their feed intake. As the consequence, average body weight and average daily weight gain also reduced compared to those fed without dried oregano leaves supplement. However, as summarized into feed conversion ratio or feed efficiency, dried oregano leaves improved the feed conversion ratio especially was significantly observed in broiler fed with highest level of dried oregano leaves at $9 \mathrm{~g} / \mathrm{kg}$ diet. This indicated that dried oregano leaves could improve the broiler gut to fully utilize each gram of feed into gram of body mass even though they fed lesser compared to those without any supplement. Even though the broiler fed and gained lesser, the carcass quality was not affected. However, heart weight percentage was significantly higher in group fed with highest level of dried oregano leaves on D42. This might be due to higher metabolism in that group which lead to higher blood circulation and led to hypertrophy of the heart muscle which indicated with the higher heart weight. As this is a preliminary study on using dried oregano leaves in broiler, there is a need to figure out how dried oregano leaves led to improvement of feed efficiency. Histological study of the gut development and antioxidant research might be useful in future investigation.

In conclusion, providing dried oregano leaves to broiler will improve their feed conversion ratio. Even though it will lead reduction in feed intake and average daily weight gain, the carcass quality is still excellent which shows that dried oregano leaves have potential as a feed additive to obtain optimum broiler performance which also very cost effective. 


\section{Acknowledgements}

The authors acknowledge the financial support from Malaysian Higher Education (MOE) and Sultan Idris Education University, Tanjung Malim,Malaysia . The authors also thank to assistance of the farm crew at Cockle Park, Morpeth, Newcastle University,UK with special thanks to Mr Mark Brett and Ms Louisa Craigs.

\section{References}

[1] Cervato, G., Carabelli, M., Gervasio, S., Cittera, A., Cazzola, R., \& Cestaro, B, "Antioxidant properties of oregano (Origanum vulgare) leaf extracts," Journal of Food Biochemistry, 24(6), 453-465, 2000.

https://doi.org/10.1111/j.1745-4514.2000.tb00715.x

[2] Daouk, R. K., Dagher, S. M., \& Sattout, E. J, “Antifungal activity of the essential oil of Origanum syriacum L,” Journal of Food Protection, 58(10), 1147-1149, 1995.

https://doi.org/10.4315/0362-028X-58.10.1147

[3] Florou-Paneri, P., Palatos, G., Govaris, A., Botsoglou, D., Giannenas, I., \& Ambrosiadis, I, “. Oregano herb versus oregano essential oil as feed supplements to increase the oxidative stability of turkey meat," International Journal of Poultry Science, 4(11), 866-871,2005.

https://doi.org/10.3923/ijps.2005.866.871

[4] Giannenas, I. A., Florou-Paneri, P., Botsoglou, N. A., Christaki, E., \& Spais, A. B, "Effect of supplementing feed with oregano and/or $\alpha$-tocopheryl acetate on growth of broiler chickens and oxidative stability of meat," Journal Animal Feed Science, 14,2005.

https://doi.org/10.22358/jafs/67120/2005

[5] Symeon, G. K., Zintilas, C., Demiris, N., Bizelis, I. A., \& Deligeorgis, S. G, "Effects of oregano essential oil dietary supplementation on the feeding and drinking behaviour as well as the activity of broilers," International Journal of Poultry Science, 9(4), 401-405, 2010.

https://doi.org/10.3923/ijps.2010.401.405 